\title{
Coping with the asylum challenge: Tightening and streamlining policies in Western Europe
}

Laurent Bernhard, University of Lausanne, FORS, Géopolis, 1015 Lausanne, Switzerland, laurent.bernhard@fors.unil.ch

David Kaufmann, University of Bern, Center of Competence of Public Management, Schanzeneckstrasse 1,3001Bern,Switzerland,david.kaufmann@kpm.unibe.ch

\begin{abstract}
To cope with the challenges posed by growing numbers of asylum seekers, Western European countries have relied on tightening policies over the last decades. We propose to complement this traditional and one-dimensional view by highlighting the importance of encompassing streamlining policies that aim to enhance the efficiency of national asylum systems through procedural accelerations and structural reforms. We argue that political conflicts over tightening and streamlining policies follow different logics. While it is hypothesised that the level of support for the former increases the more to the right a given actor position itself, approval for the latter is expected to decline with the degree of ideological extremity on the left-right axis. The empirical case relies on structured elite interviews conducted with the major political organisations involved in a referendum on the urgent modifications of the Swiss asylum law in 2013. Our quantitative findings tend to support our hypotheses.
\end{abstract}

Keywords: asylum, Western Europe, Switzerland, referendum

Acknowledgement: We would like to thank Petra Mäder for her precious assistance. 


\section{Introduction}

A record number of people currently suffer from fleeing their homes and seeking refuge. By the end of 2015, the UNHCR (2016) reported that there were 65.3 million refugees, internally displaced people and asylum seekers; the highest numbers reported since World War II. Within a year, this number rose by 12.4 million. In the Western part of the world, OECD countries received around 1.65 million asylum applications in 2015 (OECD 2016). The majority of applications were filed on the European continent where countries struggled with registering, hosting and determining the status of almost 1.3 million asylum seekers in 2016 (Eurostat 2017). The so-called 'refugee crisis' that is currently challenging European governments is not just caused by high numbers of asylum-seekers, but also by the failure of European governments to coordinate with each other in order to formulate viable political solutions to this humanitarian emergency (Scipioni forthcoming; Zaun 2017).

To cope with rising numbers of asylum seekers, migration scholars have posited that industrialised countries have increasingly relied on tightening policies over the last decades, i.e. policies that either limit access to asylum applications or attempt to reduce the attractiveness of an asylum destination country (Hatton 2009, 2012; Thielemann and Hobolth 2016). Yet some recent comparative studies find a more nuanced picture (Beine et al. 2016; de Haas, Natter, and Vezzoli forthcoming; Helbling and Kalkum forthcoming).

We propose complementing this traditional and one-dimensional view with the idea that decision-makers are increasingly relying on so-called streamlining policies. These encompassing efficiency-enhancing policies aim to speed up asylum procedures and structurally reorganise competences and responsibilities within national asylum systems. While the tightening dimension of asylum policies is well established in the academic literature, the tendency towards streamlining has been barely addressed so far. This lack of academic attention contrasts with recent policy surveys that emphasise the pervasiveness of such reforms. Most

prominently, in the title of the asylum policy section of its 2013 International Migration 
Outlook, the OECD $(2013,58)$ stated that "humanitarian policies are being streamlined and there is general trend towards deterrence". Thus, we contend that both tightening and streamlining policies should be taken into consideration in order to obtain a full picture of current asylum-related reforms in Europe.

We empirically look at the conflict structure of asylum reforms with regard to both tightening and streamlining policies. To that end, we focus on actor's positions on written policies (Czaika and de Haas 2013). ${ }^{1}$ We posit that both tightening and streamlining policies are disputed among elite actors. We further argue that political organisations respond to these two types of policies in systematically different ways by formulating two hypotheses. As to tightening, we expect actor preferences to be rooted in the new cultural conflict dimension that opposes libertarian and cosmopolitan to authoritarian and nationalist values (Kriesi et al. 2008). Our first hypothesis thus predicts that the level of support for tightening policies will increase the more to the ideological right a given political actor positions itself. Our second hypothesis predicts that the level of support for streamlining policies decreases with the degree of extremity on the left-right axis. In other words, we postulate a cross-cutting cleavage to the left-right antagonism for streamlining policies. The rationale behind this expectation relates to the fact that more extreme actors tend to express fundamental criticism of the asylum regimes that are currently available in Western Europe. As a consequence, more radical groups on either side of

\footnotetext{
${ }^{1}$ Czaika and de Haas (2013) introduced a very useful distinction between written policies, policy discourse and policy implementation when considering the effectiveness of immigration policies. As outlined in the present study's research design, the policies we selected for our empirical analysis were part of a referendum proposition, which gave rise to a nationwide policy debate in Switzerland. Thus, the advantages and disadvantages of these policies actually occurred in the framework of a much broader policy discourse. However, given that our interview questions narrowly refer to each single policy of the reform, we posit that we ultimately examine written policies.
} 
the political spectrum are reluctant to support policies that aim to enhance the efficiency of national asylum systems in a rather pragmatic manner.

The empirical analysis is based on structured elite interviews on the so-called modifications of the federal asylum law that both chambers of the Swiss Parliament enacted in September 2012. This bill presents two crucial advantages from an analytical perspective. First, since it contained the same number of tightening as streamlining policies, it can be considered to be a balanced reform package. Second, this bill proved to be highly politicised, since it subsequently gave rise to a referendum campaign. With respect to streamlining, its high saliency makes it much more likely that collective actors of various political stripes have already formed coherent preferences about these policies. The empirical findings tend to support the two above-mentioned hypotheses.

The remainder of this article is organised as follows. In section two, we summarise the tightening approach in the domain of asylum and introduce our understanding of streamlining policies. In section three, we derive our two hypotheses about the conflict structure with respect to these two distinct policies. Section four is devoted to the research design. After some considerations about the case selection, we describe our data collection strategy and present the operationalization of the key variables. The statistical testing of the hypotheses occurs in section five. Section 6 reviews the results of the quantitative analysis and addresses its implications and limitations.

\section{Theoretical framework}

Over the last decades, the ways in which asylum policies are designed and implemented in OECD countries have undergone some important changes. In Europe, the harmonisation process has constituted one of the major trends since the beginning of the $21^{\text {st }}$ century (Barbou des Places 2004; Toshkov and de Haan 2013). Europeanization led to a convergence of national asylum policies, to a formalization of asylum institutions in Southern Eastern European states 
as well as to an improvement of protection standards (El-Enany and Thielemann 2011; Kaunert and Leonard 2012; Zaun 2017). Yet scholars basically agree that asylum policies at the national level still play a crucial role (Hatton 2009; Toshkov and de Haan 2013).

So far, the academic literature tends to view national asylum policies through the prism of one single policy approach. Many authors maintain that industrialised countries have adopted more restrictive policies, thus gradually abandoning their liberal refugee regimes of the postWorld War II era (Barbou des Places 2004; Cornelius et al. 2004; Hatton 2009, 2012). Recent studies that draw on comparative migration policy datasets have detected some more nuanced patterns (Beine et al. 2016; de Haas, Natter, and Vezzoli forthcoming; Helbling and Kalkum forthcoming).

Beyond tightening policies, we argue that policies concerned with streamlining have gained currency in recent years. Asylum authorities all over Western Europe have adopted such reforms over the last decades. In the aftermath of the London Resolution of 1992, national efforts in the beginning of the 2000s followed an exclusionary logic by targeting asylum seekers with 'manifestly unfounded' claims. Since the 2010s, the scope of streamlining efforts proved to be broader in scope, given that such reforms generally aimed to enhance the efficiency of the national asylum systems.

\section{Tightening}

During the Cold War, refugees were met with sympathy in Western countries, since they were perceive to share a common rejection of communism, the enemy's political ideology. This sympathy has turned into widespread public contempt and clamour following the collapse of the Soviet Union (Hatton 2012). Popular demands for limiting the number of asylum applications have mostly been channelled by parties from the radical right, but also sometimes by moderate ones (see Bale 2008 for migration policies in general). This has caused a policy 
backlash that manifested itself in a decisive tightening all over industrialised countries (Hatton 2012).

Basically, there are two types of tightening policies. The first approach consists of making access to asylum more difficult, either by impeding the entry of asylum seekers into the territory of a destination country, or by restricting access to the refugee status determination process (Hatton 2009). The second approach focuses on reducing the attractiveness of asylum destinations. Prominent examples of such negative incentives include more restrictive refugee status determination rules and tougher welfare benefits and living conditions for asylum seekers. The first approach has been shown to be more successful in reducing the numbers of asylum applicants than the second one (Hatton 2009). However, policies that aim to limit access to the asylum process are highly controversial from legal and moral points of views since all asylum seekers are affected, regardless of whether they are in need of protection.

A number of scholars agree that national asylum policies have become more restrictive since the early 1990s (e.g. Hatton 2009; Keogh 2013; Beine et al. 2016). Based on comparative migration policy datasets, recent studies have revealed some contradictory patterns, however. While Beine et al. (2016) identify a general trend towards restrictive asylum policies, de Haas, Natter, and Vezzoli (forthcoming) show that asylum policy liberalizations have strongly decelerated since 1989 and have stopped in 2010. The analysis by Helbling and Kalkum (forthcoming) concludes that the conditions and the criteria for asylum seekers have become more liberal. At the same time, national decision-makers are found to employ more restrictive control mechanisms to prevent irregular migrants from entering the country (de Haas, Natter, and Vezzoli forthcoming; Helbling and Kalkum forthcoming). Thus, the debate about the tightening of asylum policies is not entirely settled yet, especially in Europe. Comparative migration policy scholars seem nevertheless to agree that the access to asylum destination countries has become more restrictive. 
Moreover, comparative research has established that the level of restrictiveness of asylum regimes is not the decisive factor when it comes to explaining asylum seekers' destination choice. Asylum flows are primarily driven by wars, humanitarian crises, oppression in the countries of origin and natural disasters (Schmeidl 1997; Hatton 2009; Thielemann 2012). They are also motivated by existing relationships and migrant networks (Havinga and Böcker 1999; Neumayer 2004; Barthel and Neumayer 2015). However, these crucial determinants largely escape the influence of asylum policy-makers (Thielemann 2006, 2012; Czaika and de Haas 2013). This large degree of exogeneity explains why tightening policies have proven to be rather limited in their effectiveness (Hatton 2009, 209; Thielemann 2012).

\section{Streamlining}

Policy responses for coping with growing numbers of asylum requests have not only revolved around tightening. In fact, policies that make the process more efficient are part of the toolbox of today's decision-makers. The $\operatorname{OECD}(2011,119)$ has detected a converging and continuing trend towards efficiency-enhancing reforms, notably the acceleration of refugee status determination procedures and the reliance on structural reforms. In line with OECD policy surveys, we propose calling such encompassing endeavours 'streamlining reforms'. To our knowledge, scholars have so far neglected the study of these policies. We consider streamlining reforms to be worth studying, as they currently considerably modify national asylum systems by following on a logic that is independent from tightening.

Admittedly, efficiency-enhancing policies are anything but new in the domain of asylum. In line with the sociological literature on organisations, which regards such adjustments in policies as constant practices aimed at repairing organisational deficiencies (e.g. Cooper and Burrell 1988, Brunsson 2009), Triandafyllidou (2003) showed that newly introduced management principles in Italian immigration offices strived for enhanced efficiency but in fact led to a practice of factitious efficiency. In a similar vein, Eule's $(2014,75)$ compelling study 
on the practices of German immigration offices found that these organisations constantly struggle with problems of inefficiency, and consequently undergo a constant cycle of structural failure and reform.

Another strand of literature focused on the introduction of accelerated procedures in Europe (see Oakley 2007 for an overview). Initiated by the so-called London Resolution in 1992 (Resolution on Manifestly Unfounded Applications for Asylum), exclusionary accelerated procedures were established in European countries in the early 2000s. These reforms aimed to quickly process 'manifestly unfounded' claims, thus targeting a specific category of asylum seekers (Oakley 2007, 3-4; Reneman 2013). By 2005, all EU-15 member states, and all 10 new member states that had joined the EU in 2004, had implemented some sort of exclusionary accelerated procedures (Oakley 2007, 6-7). The 'fast-track' procedure that was introduced in the UK at Oakington Immigration Reception Centre in 2000 is probably the best-studied case (e.g. Bloch and Schuster 2005, Oakley 2007, Costello 2015). However, due to their narrow focus on, these reforms proved to be limited in scope. As we will show, it is only since the early 2010 s that encompassing streamlining reforms became popular in Europe.

Broadly speaking, we can distinguish between two types of streamlining policies. The first approach is concerned with increased efficiency, simplifications and the acceleration of refugee status determination procedures, with the aim of preventing or clearing asylum request backlogs. Regarding this type of streamlining policies, Oakley $(2007,1)$ proposed a useful distinction between inclusionary and exclusionary practices: "While the main objective of an inclusionary accelerated procedure is to speedily grant an individual refugee status, the main objective of an exclusionary accelerated procedure is to speedily deny an individual refugee status". The second approach consists of structural reforms designed to re-organise competences and responsibilities between agencies and across levels of the political system in order to increase the efficiency and flexibility of national asylum systems. Indeed, high 
volatilities in the number of asylum applications generate a need for either enlarging or downsizing asylum-related infrastructures.

Encompassing streamlining reforms are often inspired by the concept of 'front-loading'. According to this concept, the standard evaluations of asylum cases (e.g. health issues) and safeguards for asylum seekers (e.g. legal advice) are implemented from the very beginning of the refugee status determination procedure. The promise of 'front-loading' is to accelerate proceedings by potentially significantly reducing the number of unnecessary appeals due to the improved quality of first instance decisions and is therefore meant to be cost-effective in the long term (Costello and Hancox 2016). Indeed, shorter waiting periods in the refugee status determination procedure increase the probability of refugees' successful economic integration (Hainmueller, Hangartner, and Lawrence 2016).

Most European countries have recently engaged in major asylum reforms that feature various types of streamlining policies. The most ambitious reform probably occurred in the Netherlands in 2011. In addition to tightening policies, the Dutch parliament decided to centralise the country's refugee status determination procedure by creating four national asylum centres. The Dutch asylum law now allows for more preparation time ahead of the asylum interview. The objective is to accelerate the subsequent procedural steps and to reduce the number of appeals (OECD 2010, 65; OECD 2013, 60).

Many European countries currently use the example of the Netherlands to reform their asylum systems. This will reinforce the trend towards streamlining in the near future. The parliaments of France (2014) and Switzerland (2015) have already passed similar laws. The French bill, for instance, aimed to reduce the average waiting period for asylum status decisions from hitherto more than two years to nine months (OECD 2015, 50). Another example is Ireland, where authorities introduced a single protection determination procedure in 2008 . All protection claims, including claims for both asylum and subsidiary protection, are now examined under a single procedure at first instance (OECD 2010, 65). Another comprehensive 
streamlining reform took place in Greece in 2011. Due to on-going pressure in the country both as a result of its geographical location as a main gate to Europe and the chronically malfunctioning of its national system - its parliament passed a new law in order to simplify asylum procedures and to create an autonomous agency with decentralised offices (OECD 2012, 111).

There are several motivations for streamlining reforms. Given that tightening policies have a limited effect on the number of asylum seekers, asylum authorities seem to increasingly turn towards streamlining policies, which allow them to have a more direct policy impact. The major rationale expressed by national governments is that destination countries can rapidly arrive at their capacity limits when faced with growing numbers of asylum applications (Byrne 2002; Oakley 2007). In the European context, asylum seekers usually pass through a rather thorough examination process. This includes asylum interviews, health checks, language analysis for determining the country of origin and sometimes even in-depth, as well as on ground, investigations of asylum claims. Such refugee status determination systems run the risk of rapidly becoming overloaded, not in the least because trained staff is only able to handle a limited number of applications in a given period of time. Time delays generate considerable additional costs in terms of housing, infrastructure and welfare benefits. In addition, appeals against status decisions are more likely to occur in chronically overloaded situations. In accordance with this view, the $\operatorname{OECD}(2013,58)$ has identified that a major reason for member states to engage in streamlining reforms is to reduce the number of asylum request backlogs that have accumulated over the years.

When confronted with high numbers of asylum requests, European countries are not only likely to face major difficulties in treating asylum requests in due time, but also in reaching the capacity limits in terms of their asylum infrastructure. This challenge is aggravated by backlogs. Such extraordinary situations require flexible ways for supplying additional lodging capacities, such as temporary refugee centres, within a short period of time. 
However, one may also argue that national decision-makers could provide additional resources to asylum systems in order to cope with such challenges. Under current circumstances, it might be the case that many governments are reluctant to provide enough resources to their asylum systems. Due to successful mobilizations by the radical right, rather hostile public opinions towards asylum seekers, and growing budgetary constraints, there might be a widespread lack of political will and courage to increase asylum capacities in contemporary Europe.

\section{Conflict structures over tightening and streamlining reforms}

In the age of globalisation, asylum policies have become a key issue in Western Europe and are characterised by an agitated public, mobilised interest groups and partisan conflict (Freeman 2006, 238). In the following, we shall set out hypotheses about the conflict structure pertaining to tightening and streamlining reforms. As will be elaborated in this section, we posit that political actors systematically respond in different ways to these two policies. We expect conflicts over tightening to be structured along the classical left-right axis. We argue that these preferences are rooted in the new cultural conflict dimension (Kriesi et al. 2008). As a consequence, we hypothesise that the amount of support for tightening policies increases the more to the right a given political actor positions itself. In contrast, we assert the existence of a cross-cutting cleavage to this left-right axis with respect to streamlining reforms. More specifically, we state that the degree of approval for streamlining reforms is negatively dependent on ideological extremity. In other words, more moderate actors should be more likely to favour streamlining policies.

The following is a theoretical explanation for our first hypothesis. When it comes to major political conflicts in contemporary Western Europe, political scientists typically draw a distinction between economic and cultural policy dimensions (Kitschelt and McGann 1997; Hooghe, Marks, and Wilson 2002; Kriesi et al. 2008). While the former refers to the opposition between state interventions and market solutions, the latter contrasts libertarian and 
cosmopolitan values on one side, with authoritarian and nationalist values on the other side. The domain of asylum policies has been associated with the cultural cleavage (Akkerman 2015). This conflict dimension has become very salient in Western Europe over the last decades. Historically, the cultural cleavage had its roots in religious confrontations. However, under the impact of secularization, the transformation of class structure and globalisation, this conflict dimension has acquired a different meaning. Currently, it refers to an antagonism between universalistic and traditionalist-communitarian values. This conflict has become increasingly politicised in Western Europe as a result of mobilisations by the new left and the Greens, as well as by the radical right (Bornschier 2010). While the former promoted issues such as ecology, participatory democracy and libertarianism, the latter primarily took a stand against European integration and advocated for a more restrictive orientation of immigration policies, thus decisively contributing to an ethnicisation of politics.In the Western European context, the left tends to adhere to cosmopolitan views, the radical right to nationalist ones and actors from the moderate right usually take an intermediate stance (Kriesi et al. 2008).

Given that tightening reforms basically aim to increase the restrictiveness of asylum policies, such undertakings are directly linked to the authoritarian/nationalist pole of the new cultural conflict dimension. It thus seems obvious to expect that the position on tightening policies is directly influenced by the left-right antagonism. More specifically, we hypothesise that the more ideologically to the right political actors position themselves, the more likely they are to agree on tightening policies. In accordance with this hypothesis, the radical right has continuously mobilised for a more restrictive orientation in the recent past, while the left and its civil society allies have kept trying to maintain the status quo or strengthen the rights of asylum seekers (Czaika and Hobolth 2016). Comparative empirical studies on immigration in general (Akkerman 2015; Duncan and Van Hecke 2008; Alonso and da Fonseca 2012), and on asylum in particular (Akkerman 2015), have further revealed that moderate parties (such as the 
Liberals, Christian Democrats, Conservatives and Agrarians) typically position themselves inbetween the radical right and the left.

As far as streamlining policies are concerned, a different logic is expected to apply. We argue that the level of support is negatively dependent on the political actors' degree of extremity on the left-right axis. Put differently, more moderate actors (such as the moderate right, the moderate left, religious organisations and public authorities) are more likely to be in favour of these policies. The objectives of acceleration and cost-reduction, which are fundamental in streamlining reforms, are assumed to be in line with the generally pragmatic problem-solving approach favoured by moderate actors in asylum matters. In addition, they may support streamlining on the grounds that such procedural reforms do not damage the humanitarian principles to which they usually adhere. In particular, these actors may take comfort from the fact that procedural improvements do not call into question the liberal asylum regime that has been dominant in Western Europe since the aftermath of World War II. These considerations may be especially pertinent to humanist actors such as religious organisations and charities.

In contrast, more radical actors on either side of the political spectrum are expected to be rather sceptical about streamlining policies. We argue that this is due to the fact that both radical groups tend to express fundamental criticism of the current national asylum regimes Hence, these actors may be reluctant to support policies that rather pragmatically aim to enhance the efficiency of existing national asylum systems by means of procedural accelerations and structural reforms. However, depending on the groups at stake, the logic behind this opposition is based on entirely different reasons. Typically, actors from the radical right believe that only tougher reforms, especially with regard to access of asylum seekers, are able to solve existing problems in the domain of asylum. In other words, these actors consider streamlining policies to be largely futile. In contrast, the radical left may be sceptical towards streamlining because these policies may jeopardise the rights of asylum seekers. These actors 
may fear that the goal of speeding up asylum procedures leads to inaccurate decision-making and that the cutting back of safeguards would be at the expense of asylum seekers. More generally, the radical left uses to advocate for comprehensive immigration liberalisations that would make the distinction between politically persecuted refugees and economic migrants obsolete (see Crawley and Skleparis (2018) for an academic critique about this distinction). Taken together, we expect that a conflict that opposes moderate to radical actors should be observable with respect to streamlining policies.

Based on these considerations, we are now equipped to formulate the following two hypotheses:

H1: The level of support for tightening policies increases the more to the right a political actor positions itself.

$\mathrm{H} 2$ : The level of support for streamlining policies decreases with the degree of extremity on the left-right axis.

\section{Research design}

\section{Case selection}

To test our hypotheses in the framework of an illustrative case study, we propose the case of the so-called urgent modifications of the federal asylum law that was enacted by both chambers of the Swiss parliament in autumn 2012. This selection is based on two major rationales. First, this bill is perfectly balanced in terms of its contents. As will be elaborated later in this section, it contained an equal number of tightening and streamlining policies. This provides us with an ideal setting for analysing political actors' preferences about the two asylum policy policies of interest. Second, the case at hand was highly politicised. This is primarily attributed to the fact that the bill was challenged through a referendum. Since citizens had the final say on this package, political elites had a strong incentive to go public with the campaign that preceded the vote. This high level of public visibility appears to be of crucial importance for encompassing 
streamlining reforms. It is only when these rather technical issues are subject to public debates that generalists, such as political parties, may begin to form coherent preferences. Otherwise, these policies remain the exclusive affair of the specialists and practitioners involved in the domain of asylum. Czaika and de Haas $(2013,494)$ maintain that 'there is often a considerable gap between tough immigration discourses by politicians and actual migration policies, which are generally much more nuanced and varied'. Due to its politicisation, the selected case presents an opportunity for examining the conscious positioning of a large population of political actors towards both tightening and streamlining. It is under such circumstances that political conflicts are likely to be waged between political camps, thus opening up the possibility for the rise of pronounced cleavages.

On 28 September 2012, the urgent modifications of the asylum law passed in both chambers of Parliament. The parties from the right adopted the bill, while those from the left rejected it. Under the leadership of the Greens and several civil society groups, many organisations decided to force a vote by collecting the 50,000 signatures required to do so within 100 days. In January 2013, this ad hoc coalition succeeded in qualifying the urgent modifications of the asylum law to the ballot. In addition to the members of the referendum committee, the Social Democrats and the Catholic and Protestant Churches recommended the rejection of the bill. In contrast, federal and cantonal authorities, parties from the right and some conservative citizen groups were in favour of the urgent modifications. On 9 June 2013, Swiss voters accepted the bill by a majority of $78.2 \%$.

When examining the contents of the bill, four policies can be considered to be pursuing a tightening objective, while the remaining four pursue a streamlining logic. In regards to the former, the ban on applying for asylum at Swiss embassies constituted one of the most debated policy. Since Switzerland was the only remaining European country to offer this option, the Government pleaded for its abolishment. A second tightening policy denied refugee status for deserters. This deterrence measure primarily targeted young Eritrean men, as many of them fled 
abroad on the grounds that they were forced to perform military service for an undetermined period of time. Moreover, the policy allowed for the creation of special centres housing socalled troublemakers (i.e. asylum seekers who refuse to cooperate with the authorities). Finally, Parliament decided to reduce the appeal period for rejected asylum requests. The period decreased from 30 to 5 working days for applications that the authorities considered to be incredible as well as for feasible deportations. The same reduction was decided for asylum seekers originating from a list of defined 'safe countries'.

With respect to the streamlining, a first policy concerned the testing of a planned structural reform, which aimed to dramatically reduce the average application processing time for the majority of cases from an average of 700 days to around 100. To that end, the Swiss authorities relied on 'front-loading' principle by modelling their reform on the Dutch example. In addition, the federal authorities obtained greater powers over the cantons (i.e. the 26 member states) in order to enhance their ability to manoeuvre and cope with the challenge posed by volatile numbers of asylum seekers. The Confederation was allowed to use its own facilities and buildings without requiring cantonal authorization for a maximum period of three years. This is a rather controversial issue in the Swiss context, since establishing new asylum centres often triggers local protests, not least due to a perceived threat of increased delinquency. In this respect, there were concerns that this measure would harm the competences of the cantons. In return for this concession, Parliament enacted two policies to benefit the cantons. First, the Confederation could provide the affected cantons with flat-rate subsidies for covering additional security costs. Second, the amendment stipulated that the federal state could financially contribute to employment programs conducted by the cantons, municipalities, or third parties.

\section{Data collection}


The empirical analysis draws on data gathered from structured elite interviews. We decided to select political organisations that actively took part in the 2013 Swiss referendum campaign on the urgent modifications of the federal law on asylum. We identified 31 organisations on the basis of various sources: the parliamentary debates, the campaign for the collection of signatures, voting recommendations, the press and websites more generally. In addition, to complete the set of organisations, this information was cross-referenced using the people that were interviewed. Given this pragmatic procedure, we feel confident that we have included the most important organisations. ${ }^{2}$ For each organisation, we scheduled an interview with the person responsible for the ballot proposition at stake in the run-up to the campaign. From the organisations selected, we decided to remove those that had no impact at all in the directdemocratic campaign in question. Based on a reputational power indicator, this proved to be the case for three organisations, thus leaving us with 28 observations. ${ }^{3}$

When applying the criteria described above, we obtain a population of actors that strongly resembles that of the network analysis conducted by Statham and Geddes (2006) on British migration elites. Indeed the organisations we selected can similarly be assigned to three main categories: state actors $(\mathrm{N}=3)$, political parties $(\mathrm{N}=10)$, and interest groups $(\mathrm{N}=15)$. Table 1 provides an overview of the included organisations.

\footnotetext{
${ }^{2}$ Given that Swiss political elites are motivated to participate in academic interviews, we succeeded in including all political organizations we considered to be of importance. We are thus dealing with an exhaustive actor selection.

${ }^{3}$ Our measure for power draws on a question asked immediately after the vote had taken place. On a list that contained all organisations that we had interviewed in front of the campaign, selected campaign managers were invited to mark those organisations that, from their point of view, had been particularly influential. It turned out that the Evangelical People's Party (EVP), the labour union Unia and the conservative youth organisation Young4fun.ch were not mentioned at all. Hence, these three organisations were excluded from the analysis.
} 
Table 1: Selected political organizations

\begin{tabular}{|c|c|c|c|}
\hline Category & Subcategory & Official name & $\begin{array}{l}\text { Self- } \\
\text { reported } \\
\text { positioning } \\
\text { on the left- } \\
\text { right scale } \\
(0-10)\end{array}$ \\
\hline \multirow[t]{2}{*}{ State actors } & $\begin{array}{l}\text { Federal } \\
\text { administration }\end{array}$ & $\begin{array}{l}\text { Federal Department of Justice and Police } \\
\text { (EJPD) } \\
\text { Federal Office for Migration (BFM) }\end{array}$ & 5 \\
\hline & $\begin{array}{l}\text { Sub-national } \\
\text { administration }\end{array}$ & $\begin{array}{l}\text { Cantonal Ministers of Justice and Police } \\
\text { (KKJPD) }\end{array}$ & 6 \\
\hline \multirow[t]{3}{*}{ Political parties } & Left & $\begin{array}{l}\text { Social Democrats (SP) } \\
\text { Young Socialists (JUSO) } \\
\text { Greens (GPS) } \\
\text { Young Greens (JG) }\end{array}$ & $\begin{array}{l}2 \\
1 \\
2 \\
2\end{array}$ \\
\hline & Moderate right & $\begin{array}{l}\text { Christian Democrats (CVP) } \\
\text { Conservative Democratic Party (BDP) } \\
\text { Liberals (FDP) } \\
\text { Green Liberals (GLP) }\end{array}$ & $\begin{array}{l}5 \\
6 \\
7 \\
5\end{array}$ \\
\hline & Radical right & $\begin{array}{l}\text { Swiss People's Party (SVP) } \\
\text { Young Swiss People's Party (JSVP) }\end{array}$ & $\begin{array}{c}8 \\
10 \\
\end{array}$ \\
\hline \multirow[t]{6}{*}{$\begin{array}{l}\text { Civil society } \\
\text { groups }\end{array}$} & $\begin{array}{l}\text { Conservative } \\
\text { groups }\end{array}$ & $\begin{array}{l}\text { Pro Libertate (ProLib) } \\
\text { Pikom }\end{array}$ & $\begin{array}{l}9 \\
8\end{array}$ \\
\hline & Charities & $\begin{array}{l}\text { Caritas } \\
\text { Charity of the Protestant Churches of } \\
\text { Switzerland (HEKS) } \\
\text { Swiss Workers Aid (SAH) } \\
\text { Protestant Social Centre (CSPGE) }\end{array}$ & $\begin{array}{l}5 \\
5 \\
1 \\
2\end{array}$ \\
\hline & $\begin{array}{l}\text { Immigrant } \\
\text { organizations }\end{array}$ & $\begin{array}{l}\text { Solidarity without frontiers (sosf) } \\
\text { Coordination against exclusion and } \\
\text { xenophobia (stop) } \\
\text { Living together (vivre) }\end{array}$ & $\begin{array}{l}2 \\
2 \\
1\end{array}$ \\
\hline & $\begin{array}{l}\text { Religious } \\
\text { organizations }\end{array}$ & $\begin{array}{l}\text { Federation of Swiss Protestant Churches } \\
\text { (SEK) } \\
\text { Justitia et Pax (JusPax) } \\
\text { AGORA }\end{array}$ & $\begin{array}{l}5 \\
5 \\
5\end{array}$ \\
\hline & $\begin{array}{l}\text { Human rights } \\
\text { organizations }\end{array}$ & $\begin{array}{l}\text { Swiss Democratic Lawyers (DJS) } \\
\text { Amnesty International (AI) }\end{array}$ & $\begin{array}{l}3 \\
5\end{array}$ \\
\hline & $\begin{array}{l}\text { Pacifist } \\
\text { organization }\end{array}$ & $\begin{array}{l}\text { Group for a Switzerland without an army } \\
\text { (GSoA) }\end{array}$ & 1 \\
\hline
\end{tabular}

Our analysis includes three state actors: two bodies of the federal administrations (the Federal Department of Justice and Police, and the more specialised Federal Office for Migration) and one at the sub-national level (the Cantonal Ministers of Justice and Police). The political parties include four from the left (the Social Democrats, the Greens and their respective youth 
organisations) and the moderate right (Christian Democrats, the Conservative Democratic Party, the Liberals and the Green Liberals). In addition, we included the Swiss People's Party and its youth organisation (JSVP) from the radical right. As far as interest groups are concerned, all of them can be considered to be civil society actors. This demonstrates that economic interest associations (such as business groups and labour unions) tend to keep a low profile in the domain of asylum. With the exception of two conservative groups (Pro Libertate, a patriotic association, and Pikom, an organisation that campaigns for more restrictive immigration policies), civil society groups were against the bill. These interest groups include four charities (Caritas, the Charity of the Protestant Churches of Switzerland, Swiss Workers Aid and the Geneva-based Protestant Social Centre), three domain-specific organisations that support asylum seekers and immigrants ('Solidarity without frontiers', as well as the two Frenchspeaking 'Coordination against exclusion and xenophobia', and 'Living together'), three religious organisations (the Federation of Swiss Protestant Churches, 'Justitia et Pax', a Commission of the Conference of Swiss Bishops and AGORA, a pastoral care for refugees in Geneva), two human rights organisations (Swiss Democratic Jurists and Amnesty International), as well as one pacifist organisation (the 'Group for a Switzerland without an army'). Due to the large representation of civil society groups, the opponents to the ballot proposition $(\mathrm{N}=17)$ outnumber the supporters $(\mathrm{N}=11)$.

\section{Operationalization}

We now present the operationalization of our key variables. In order to measure the dependent variables, i.e. the preferences of the selected organisations regarding tightening and streamlining policies, we rely on a series of questions about their position on the 2013 ballot proposition. To that end, campaign managers were presented with a list of the eight policies at stake. These included: 1) the abolishment of the embassy procedure, 2) the new rule on desertion, 3) the introduction of special centres for so-called troublemakers, 4) the reduction in 
the time of the appeal period, 5) the testing of the planned structural reform, 6) the increased powers for the federal state over cantons with respect to the use of facilities and buildings, 7) the federal flat-rate subsidies for security costs and 8) the federal state's financial contribution for employment programs. Respondents were invited to state the preferences of their respective organisation on a five-level-scale that ranges from 1 (strongly disagree) to 5 (strongly agree). To assess the number of dimensions, we factor-analyse the eight items by using principal component analysis (PCA) with varimax rotation. Table 2 shows that this procedure retains two factors with eigenvalues higher than one. The results are basically in line with our theoretical expectations. The first, and stronger, factor reflects the tightening dimension. As expected, the items regarding desertion, the procedure at embassies, special centres and the reduction of the appeal period highly load on this factor. The second factor comes very close to the notion of streamlining. Three of the four remaining items belong to this second dimension, with factor loadings respectively higher than 0.7 . This applies to the increased federal powers over facilities and buildings, the employment programs and the testing of the planned asylum reform. The only exception concerns the flat-rate subsidies. This item proves to not be discriminatory in nature, as it moderately loads on both factors. To measure the actors' preferences on tightening and streamlining, we extracted the various organisations' scores on the first and second factor loadings. 
Table 2: Factor loadings of the ballot-specific issue (Principal factor analysis with Varimax rotation)

\begin{tabular}{|l|ll|}
\hline Issue items & $\begin{array}{l}\text { Tightening } \\
\text { (factor 1) }\end{array}$ & $\begin{array}{l}\text { Streamlining } \\
\text { (factor 2) }\end{array}$ \\
\hline No guaranteed refugee status for deserters & $\mathbf{0 . 9 8 9 2}$ & 0.0556 \\
Ban of applying for asylum at embassies & $\mathbf{0 . 9 7 3 7}$ & 0.0872 \\
Special centres for troublemakers & $\mathbf{0 . 9 5 3 7}$ & 0.1331 \\
Reduction of appeal period & $\mathbf{0 . 9 4 1 1}$ & 0.0803 \\
Flat-rate subsidies for security cost & 0.5831 & 0.6165 \\
Testing of new asylum procedure (Dutch model) & 0.4323 & $\mathbf{0 . 7 2 4 5}$ \\
More federal power on facilities and buildings & 0.0467 & $\mathbf{0 . 8 0 7 2}$ \\
Federal contributions to employment programs & -0.1376 & $\mathbf{0 . 8 0 7 0}$ \\
& & \\
Eigenvalue & 4.6981 & 1.8105 \\
Correlation & 0.3771 & \\
Number of observations & 28 & \\
\hline
\end{tabular}

We now turn to the two independent variables. Regarding the actors' position on the left-right dimension, we asked respondents to position their respective organisation on a scale that ranges from 0 (completely left) to 10 (completely right). The last column in Table 1 shows the selfreported position of each organisation that is included in this analysis. Regarding the ideological extremity, we calculated the amount differences of these self-reported positions from the middle category (5). This means that the most extreme actors on either side obtain the maximum values of 5 , while those in the centre stand at 0.

\section{Empirical results}

To obtain a first impression of the empirical validity of the two hypotheses of interest here, we ran bivariate correlations. Both associations turn out to be rather substantial and in line with our theoretical expectations. This especially applies to the first hypothesis, where Pearson's correlation coefficient between the left-right positioning and the support of tightening policies amounts to 0.77 . It appears that support of more restrictive approaches increases the more to the right a given political actor places itself. For the second hypothesis, there is a negative relation of -0.56 between the extent of ideological extremity and the agreement on streamlining. 
Thus, more moderate actors tend to be more likely to declare themselves in favour of streamlining policies than more extreme organisations.

Let us now test whether these observed patterns can be confirmed in a multivariate setting. Given that we are dealing with a small number of observations $(\mathrm{N}=28)$, we decided to rely on parsimonious models by limiting ourselves to a few explanatory factors. ${ }^{4}$ In addition to the two dimensions of to the organisations' core ideology (i.e. left-right and extremity), we control for the influence of policy core beliefs, actor types and language region. For the former, we take into account the various actors' degree of xenophobia. To that end, we follow the guidance of Sniderman, Hagendoorn, and Prior (2004). We and asked five questions about the respondents' perceived economic, cultural and safety threats due to immigration. ${ }^{5}$ When conducting a factor analysis with varimax rotation of the answers respondents gave on a fivelevel Likert scale, we obtain a single factor, which we use as an indicator for the degree of xenophobia.

Regarding actor types, we distinguish between political parties, civil society groups and state actors. The state actors are the reference category. As far as language regions are concerned, we make use of a dichotomous variable. The four organisations based in the Frenchspeaking part of Switzerland take the value of ' 1 '. We decided to account for language region since elite actors of the French language regions tend to hold a more liberal position on

\footnotetext{
${ }^{4}$ This strategy enables an acceptable number of degrees of freedom. In addition, we need to mention that we relied on an iterative approach by adding one control variable at a time. These models did not change our findings in terms of statistical significance.

${ }^{5}$ The wording of these items is as follows: 1) I am afraid of increased violence and acts of vandalism committed by foreigners in my neighborhood, 2) Because of foreigners I am concerned about my personal economic situation, 3) I am afraid of increasing violence and vandalism committed by foreigners in Switzerland, 4) I am afraid of the threat of the Swiss culture due to foreigners, 5) Because of foreigners I am concerned about the economic situation of Switzerland.
} 
immigration-related issues than the rest of the country (Bernhard 2012, 47). Table 3 shows the results of two OLS regression models. With respect to tightening (Model I), it turns out that the more to the right organisations place themselves, the much more likely they are to be in favour of tightening policies. This positive association, which is significant at the $1 \%$ error margin, is consistent with our theoretical expectation. This also tends to be the case with respect to the second hypothesis. As is visible from Model II, there is a negative relationship between the degree of ideological extremity and the level of support for streamlining policies. However, this statistical association is only secured at the $10 \%$ error margin. Thus, there is only weak empirical evidence that moderate organisations are more prone to approve streamlining policies than more extreme ones.

Table 3: OLS regression models explaining factor loadings for tightening and streamlining

\begin{tabular}{lll}
\hline & $\begin{array}{l}\text { Model I } \\
\text { Tightening }\end{array}$ & $\begin{array}{l}\text { Model II } \\
\text { Streamlining }\end{array}$ \\
\hline Left-right & $0.229^{* * *}$ & 0.029 \\
& $(3.71)$ & $(0.30)$ \\
Ideological & 0.098 & $-0.203^{*}$ \\
Extremity & $(1.39)$ & $(-1.86)$ \\
Xenophobia & 0.177 & -0.396 \\
& $(1.06)$ & $(-1.52)$ \\
Parties & $0.512^{* *}$ & $0.559^{*}$ \\
& $(2.46)$ & $(1.73)$ \\
State actors & $1.659^{* * *}$ & $0.938^{*}$ \\
& $(5.43)$ & $(1.97)$ \\
French-speaking & 0.051 & 0.078 \\
Organizations & $(0.18)$ & $(0.19)$ \\
Constant & $-1.565^{* * *}$ & -0.039 \\
& $(-4.31)$ & $(-0.07)$ \\
\hline$N$ & 28 & 28 \\
Adjusted $R^{2}$ & 0.88 & 0.44 \\
\hline p $<0.10, * * \mathrm{p}<0.05, * * * \mathrm{p}<0.01$ & \\
T-values in parentheses & \\
Note: Civil society groups are the reference category for the actor types.
\end{tabular}


The results of the control variables are as follows. The degree of xenophobia does not systematically affect asylum-specific preferences. ${ }^{6}$ Regarding actor types, the most consistent finding pertains to political parties and state actors. These two groups appear to support both streamlining and tightening to a higher extent than civil society groups, which serve as reference group in this analysis. However, it is worth noting that the actor-related gap is much more pronounced for the tightening ( $1 \%$ error margin) than for the streamlining ( $10 \%$ error margin). The fact that organisations from civil society are generally more critical may be attributed to their disadvantaged position in the Swiss political system. Unlike state actors and parties, these groups typically do not enjoy direct access to the decision-making arena. As a consequence, their concerns are less likely to be considered in parliamentary bills. This may in turn nurture a higher degree of opposition towards the policies adopted. With respect to language regions, we are not able to detect any consistent pattern. More specifically, organisations from the Frenchspeaking part do no differ themselves from the remaining elite actors when it comes to their asylum-specific preferences.

\section{Conclusion}

Confronted with rising numbers of asylum requests, numerous European countries have since the 2010s enacted streamlining reforms, which refer to encompassing efficiency-enhancing policies that are designed to enhance the efficiency of national asylum systems through procedural accelerations and structural reforms. In this article, we have argued that the academic literature has neglected these policies so far. By relying on structured elite interviews about the urgent modifications to the Swiss asylum law, we have been able to show that the conflict structures over these two major reform trends follow entirely different logics. Actor

\footnotetext{
${ }^{6}$ With respect to tightening, this noteworthy non-finding is primarily due to the fact that the explanatory power of the left-right scale tends to outweigh the effects that stem from xenophobic attitudes.
} 
preferences for tightening policies are strongly influenced by their ideological positioning on the left-right axis. The level of support for these policies generally increases the more to the right a given political organisation position itself. In contrast, the degree of approval for streamlining policies tends to be higher the more to the centre political actors position themselves on this scale. This quantitative analysis showed that the statistical associations attain far higher levels of significance for the well-established conflict on tightening policies than for those that refer to streamlining.

The main findings of this empirical contribution suggest that the composition of reform coalitions highly depends on the issue at stake. Tightening policies are clearly favoured by the radical right and opposed by the left and its civil society allies. The remaining actors usually take intermediate positions. Due to their pivotal role in most political systems in Western Europe, the moderate right may hold the balance of power when it comes to enacting more restrictive policies. In cases in which the moderate right lacks a parliamentary majority, such reforms may come about on the basis of agreements with the radical right. In contrast, streamlining reforms may typically be the result of coalitions between moderate and pragmatic forces from the left and the right, given that more radical actors on either side of the class conflict have been found to be rather reluctant to support such policies.

More generally, the two-dimensional setting proposed here may provide a more accurate picture in terms of actor configurations. By combining the preferences of tightening and streamlining policies, we can speculate about the existence of four distinctive types of political organisations in Western Europe in relation to asylum issues. Although moderate right actors may be somewhat hesitant about applying more restrictiveness to the asylum system, they may usually be in favour of both tightening and streamlining. In contrast, actors from the radical left may reject both approaches. The radical right may endorse tightening and be sceptical about streamlining endeavours. The opposite may hold true for pragmatic actors from the left. Even though future research will have to clarify how, and to what extent, streamlining reforms create 
a division among both the left and the right, it seems obvious that a more nuanced conceptualisation has the potential to more adequately reflect actors' preferred policy outcomes than is the case for a single policy dimension. In a similar vein, Bale $(2008,463)$ maintained that moderate right parties are more than capable of thinking, talking and acting for themselves, even though they may be under pressure from the radical right on immigration issues. A similar logic of differentiation may be applicable to the left. At a minimum, our empirical analysis concludes that the moderate left is much more prone to embarking on streamlining reforms on asylum matters than those from the radical left. However, when it comes tightening, these two ideological groups have been shown to hold similar views.

Despite that fact that this empirical analysis reveals some promising findings, there are a number of reasons they should be considered with care. First, the empirical case used here only deals with one case of reform. While the selected reform case had the crucial advantage of being perfectly balanced (it contained as many tightening as streamlining policies), these results have to be taken with a pinch of salt when it comes to the issue of generalisability. It remains to be seen whether such empirical patterns are observable beyond the specific context studied here. Because the urgent modifications of the Swiss asylum law were subject to a referendum campaign, the preferences of political actors regarding streamlining policies may have been much more crystallised in this study than would have been the case in instances of low saliency. In other words, we posit that our results are only valid for situations when both tightening and streamlining policies are well established among political elites. However, given that both the topic of asylum in general, and streamlining reforms in particular, are increasingly high on the agenda in these times of record high asylum applications, we anticipate that this may be the case all over Europe in the near future. Hence, we would like to plead for studies that comparatively examine the various forms and effects of streamlining asylum policies across countries. 


\section{References}

Akkerman, Tjitske. 2015. "Immigration policy and electoral competition: A fine-grained analysis of party positions over the past two decades." Party Politics 21 (1): 54-67.

Alonso, Sonia, and Sara Claro da Fonseca. 2012. "Immigration, left and right." Party Politics 18 (6): 865-884.

Bale, Tim. 2008. "Politics matter: A conclusion." Journal of European Public Policy 15 (3): 453-463.

Barbou des Places, Ségolène. 2004. "Taking legal rules into consideration: EU asylum policy and regulatory competition." Journal of Public Policy 24 (1): 75-98.

Barthel, Fabian, and Eric Neumayer. 2015. "Spatial Dependence in Asylum Migration." Journal of Ethnic and Migration Studies 41 (7): 1131-1151.

Beine, Michel, Anna Boucher, Brian Burgoon, Mary Crock, Justin Gest, Michael Hiscox, Patrick McGovern, Hillel Rapoport, Joep Schaper, and Eiko Thielemann. 2016. "Comparing immigration policies: An overview from the IMPALA database." International Migration Review 50 (4): 827-863.

Bernhard, Laurent. 2012. Campaign Strategy in Direct Democracy. Basingstoke: Palgrave Macmillan.

Bloch, Alice, and Liza Schuster. 2005. "At the extremes of exclusion: deportation, detention and dispersal." Ethnic and Racial Studies 28 (3): 491-512.

Bornschier, Simon. 2010. Cleavage Politics and the Populist Right: The New Cultural Conflict in Western Europe. Philadelphia: Temple University Press.

Brunsson, Nils. 2009. Reform as Routine: Organizational Change in the Modern World. Oxford: Oxford University Press.

Byrne, Rosemary. 2002. "Future perspectives: Accession and asylum in an expanded European Union" In New Asylum Countries? Migration Control and Refugee Protection in an Enlarged European Union, edited by Byrne, Rosemary, Gregor Noll, and Jens Vested-Hansen, 383-391. The Hague: Kluwer.

Cooper, Robert, and Gibson Burrell. 1988. "Modernism, postmodernism and organizational analysis: An introduction." Organization Studies 9 (1): 91-112.

Cornelius, Wayne A., Takeyuki Tsuda, Philip L. Martin and James F. Hollifield, eds. 2004. Controlling Immigration: A Global Perspective. Stanford: Stanford University Press.

Costello, Cathryn. 2015. "Immigration detention: The grounds beneath our feet." Current Legal Problems 68 (1): 143-177.

Costello, Cathryn, and Emily Hancox. 2016. "The Recast Asylum Procedures Directive 2013/32/EU: Caught between the Stereotypes of the Abusive Asylum-Seeker and the Vulnerable Refugee." In Reforming the Common European Asylum System: The New European 
Refugee Law, edited by Chetail, Vincent, Philippe De Bruycker, and Francesco Maiani, 377445. Leiden: Koninklijke Brill.

Crawley, Heaven and Dimitris Skleparis. 2018. "Refugees, migrants, neither, both: categorical fetishism and the politics of bounding in Europe's 'migration crisis'." Journal of Ethnic and Migration Studies. 44 (1): 48-64.

Czaika, Mathias, and Hein De Haas. 2013. "The effectiveness of immigration policies." Population and Development Review 39 (3): 487-508.

Czaika, Matthias, and Mogens Hobolth. 2016. "Do restrictive asylum and visa policies increase irregular migration into Europe?” European Union Politics 17 (3): 345-365.

De Haas, Hein, Katharina Natter, and Simona Vezzoli. forthcoming. "Growing restrictiveness or changing selection? The nature and evolution of migration policies." International Migration Review.

Duncan, Fraser, and Steven Van Hecke. 2008. "Immigration and the transnational European centre-right: A common programmatic response?" Journal of European Public Policy 15 (3): $432-452$.

El-Enany, Nadine, and Eiko Thielemann. 2011. "The impact of the EU on national asylum policies." In The Area of Freedom, Security and Justice: Myth or Reality? Taking Stock of the Lisbon Treaty and the Stockholm Programme, edited by Wolff, Sarah, Flora Goudappel and Japp de Zwaan, 97-116. The Hague: TMC Asser Press.

Eule, Tobias. 2014. Inside Immigration Law: Migration Management and Policy Application in Germany. Ashgate Publishing.

EUROSTAT. 2017. Database: Asylum and First time Asylum Applicants [migr_asyappctza].

Freeman, Gary P. 2006. "National models, policy types, and the politics of immigration in liberal democracies." West European Politics 29 (2): 227-247.

Hainmueller, Jens, Dominik Hangartner, and Duncan Lawrence. 2016. "When lives are put on hold: Lengthy asylum processes decrease employment among refugees" Science Advances 2 $(8)$.

Hatton, Timothy J. 2009. "The rise and fall of asylum: What happened and why?" The Economic Journal 119 (535): 183-213.

Hatton, Timothy J. 2012. Seeking Asylum: Trends and Policies in the OECD. London: Centre for Economic Policy Research (CEPR).

Havinga, Tetty, and Anita Böcker. 1999. "Country of asylum by choice or by chance: Asylumseekers in Belgium, the Netherlands and the UK." Journal of Ethnic and Migration Studies 25 (1): 43-61.

Helbling, Marc, and Dorina Kalkum. forthcoming. "Migration Policy Trends in OECD Countries." Journal of European Public Policy. 
Hooghe, Lisbet, Gary Marks, and Carole J. Wilson. 2002. "Does left/right structure party positions on European integration?” Comparative Political Studies 35 (8): 965-989.

Kaunert, Christian, and Sarah Leonard. 2012. "The development of the EU asylum policy: venueshopping in perspective." Journal of European Public Policy 19 (9): 1396-413.

Keogh, Gerard. 2013. "Modelling Asylum Migration Pull-Force Factors in the EU-15." The Economic and Social Review 44 (3): 371-399.

Kitschelt, Herbert, and Anthony J. McGann. 1997. The Radical Right in Western Europe: A Comparative Analysis. Ann Arbor: University of Michigan Press.

Kriesi, Hanspeter, Edgar Grande, Romain Lachat, Martin Dolezal, Simon Bornschier, and Timotheos Frei. 2008. West European Politics in the Age of Globalization. Cambridge: Cambridge University Press.

Neumayer, Eric. 2004. “Asylum Destination Choice What Makes Some West European Countries More Attractive Than Others?” European Union Politics 5 (2): 155-180.

Oakley, Sharon. 2007. "Accelerated Procedures for Asylum in the European Union: Fairness Versus Efficiency.” Sussex Migration Working Paper no. 43.

OECD. International Migration Outlook. Paris, several editions.

Reneman, Marcelle. 2013. "Speedy asylum procedures in the EU: Striking a fair balance between the need to process asylum cases efficiently and the asylum applicant's EU right to an effective remedy." International Journal of Refugee Law, 25 (4): 717-748.

Schmeidl, Susanne. 1997. "Exploring the Causes of Forced Migration: A Pooled Time-Series Analysis, 1971-1990." Social Science Quarterly 78 (2): 284-308.

Scipioni, Marco. forthcoming. "Failing forward in EU migration policy? EU integration after the 2015 asylum and migration crisis." Journal of European Public Policy.

Sniderman, Paul M., Louk Hagendoorn, and Markus Prior. 2004. "Predispositional factors and situational triggers: Exclusionary reactions to immigrant minorities." American Political Science Review 98 (1): 35-50.

Statham, Paul, and Andre Geddes. 2006. "Elites and the 'organised public': Who drives British immigration politics and in which direction?" West European Politics 29 (2): 248269.

Thielemann, Eiko. 2006. "The Effectiveness of Governments' attempts to control unwanted migration." In Immigration and the Transformation of Europe, edited by Craig A. Parsons, and Timothy M. Smeeding, 442-472. Cambridge: Cambridge University Press.

Thielemann, Eiko. 2012. "How effective are national and EU policies in the area of forced migration?" Refugee Survey Quarterly 31 (4): 21-37. 
Thielemann, Eiko, and Mogens Hobolth. 2016. "Trading numbers vs. rights? Accounting for liberal and restrictive dynamics in the evolution of asylum and refugee policies." Journal of Ethnic and Migration Studies 42 (4): 643-664.

Triandafyllidou, Anna. 2003. "Immigration policy implementation in Italy: organisational culture, identity processes and labour market control." Journal of Ethnic and Migration Studies 29 (2): 257-297.

Toshkov, Dimiter, and Laura de Haan. 2013. "The Europeanization of asylum policy: An Assessment of the EU impact on asylum applications and recognitions rates." Journal of European Public Policy 20 (5): 661-683.

UNHCR. 2016. Global Trends: Forced Displacement in 2015.

Zaun, Natascha. 2017. EU Asylum Policies: The Power of Strong Regulating States. Cham: Springer. 